\title{
Herbivore corridors sustain genetic footprint in plant populations: a case for Spanish drove roads
}

\author{
Alfredo García-Fernández ${ }^{1}$, Pablo Manzano ${ }^{\text {Corresp., } 2,3,4}{ }^{4}$ Javier Seoane $^{3}$, Francisco M Azcárate ${ }^{3}$, Jose M Iriondo ${ }^{1}$, \\ Begoña Peco ${ }^{3}$ \\ 1 Área de Biodiversidad y Conservación, Universidad Rey Juan Carlos, Móstoles, Madrid, Spain \\ 2 Commission on Ecosystem Management, International Union for Conservation of Nature, Nairobi, Kenya \\ 3 Terrestrial Ecology Group - Departamento de Ecología, Centro de Investigación en Biodiversidad y Cambio Global (CIBG), Universidad Autónoma de \\ Madrid, Madrid, Spain \\ 4 HELSUS, Faculty of Biological and Environmental Sciences, University of Helsinki, Helsinki, Finland
}

Corresponding Author: Pablo Manzano

Email address: pablo.manzano.baena@gmail.com

Habitat fragmentation is one of the greatest threats to biodiversity conservation and ecosystem productivity that are mediated by direct human impact. Its consequences include genetic depauperation, comprising phenomena such as inbreeding depression or reduction in genetic diversity. While the capacity of wild and domestic herbivores to sustain long-distance dispersal has been proven, the impact of herbivore corridors in plant population genetics remains to be observed. We conducted this study in the Conquense Drove Road in Spain, with a sustained use by livestock during centuries where transiting herds passed by twice a year en route to winter and summer pastures. We compared genetic diversity and inbreeding coefficients of Plantago lagopus populations in the drove road with populations in the surrounding agricultural matrix, at varying distances from human settlements. We observed significant differences for coefficients of inbreeding between the drove road and the agricultural matrix, as well as significant trends for higher genetic diversity and population nestedness around human settlements. Trends for higher genetic diversity in drove roads may be present, although they were only marginally significant with the available sample size. The resulting functional landscape has human settlements as dispersal hotspots, while the drove road would confirm its pollinator reservoir role observed in other studies, and possibly also as a linear structure facilitating long-distance dispersal in an agricultural matrix where local $P$. lagopus populations depend rather on short-distance dispersal. These results highlight the role of herbivore corridors for conserving the migration capacity of plants, and they contribute as well in understanding the role of dispersal related to human activities for the spread of invasive species. 


\section{Herbivore corridors sustain genetic footprint in plant populations: a case for Spanish drove roads}

Alfredo García-Fernández ${ }^{1}$, Pablo Manzano ${ }^{2}{ }^{4}$, Javier Seoane ${ }^{3}$, Francisco M Azcárate ${ }^{3}$, Jose M Iriondo $^{1}$, Begoña Peco ${ }^{3}$

${ }^{1}$ Área de Biodiversidad y Conservación, Universidad Rey Juan Carlos, Móstoles, Madrid, Spain

${ }^{2}$ Commission on Ecosystem Management, International Union for Conservation of Nature, Nairobi, Kenya

${ }^{3}$ Terrestrial Ecology Group - Departamento de Ecología, Centro de Investigación en Biodiversidad y Cambio Global (CIBC), Universidad Autónoma de Madrid, Madrid, Spain

${ }^{4}$ HELSUS, Faculty of Biological and Environmental Sciences, University of Helsinki, Helsinki, Finland

Corresponding Author:

Pablo Manzano ${ }^{2}$

P. O Box 68200, Nairobi, 00200, Kenya

Email address: pablo.manzano.baena@gmail.com

25

26 


\section{ABSTRACT}

28 Habitat fragmentation is one of the greatest threats to biodiversity conservation and ecosystem

29

30

31

32

33

34

35

36

37

38

39

40

41

42

43

44

45

46

47

48

49

50

51

52

53

54

55

56

57

58

59

60

61

62

63

64

65

66

67

68

69

70

71

72 productivity that are mediated by direct human impact. Its consequences include genetic depauperation, comprising phenomena such as inbreeding depression or reduction in genetic diversity. While the capacity of wild and domestic herbivores to sustain long-distance dispersal has been proven, the impact of herbivore corridors in plant population genetics remains to be observed. We conducted this study in the Conquense Drove Road in Spain, with a sustained use by livestock during centuries where transiting herds passed by twice a year en route to winter and summer pastures. We compared genetic diversity and inbreeding coefficients of Plantago lagopus populations in the drove road with populations in the surrounding agricultural matrix, at varying distances from human settlements. We observed significant differences for coefficients of inbreeding between the drove road and the agricultural matrix, as well as significant trends for higher genetic diversity and population nestedness around human settlements. Trends for higher genetic diversity in drove roads may be present, although they were only marginally significant with the available sample size. The resulting functional landscape has human settlements as dispersal hotspots, while the drove road would confirm its pollinator reservoir role observed in other studies, and possibly also as a linear structure facilitating long-distance dispersal in an agricultural matrix where local $P$. lagopus populations depend rather on short-distance dispersal. These results highlight the role of herbivore corridors for conserving the migration capacity of plants, and they contribute as well in understanding the role of dispersal related to human activities for the spread of invasive species.

\section{INTRODUCTION}

Increased habitat fragmentation has been perceived as a major worldwide threat for ecosystems and biodiversity for the last decades (Fahrig 2003). Fragmentation limits population size and reduces seed and pollen flow among populations, leading to genetic drift and reduction in withinpopulation genetic diversity. This genetic impoverishment can limit evolutionary potential, promote selfing and therefore, decrease population viability through inbreeding depression. Such effects impact not only biodiversity conservation (Ouborg et al. 2006), but also ecosystem productivity (Crutsinger et al. 2006) and microevolutionary responses (Matesanz et al. 2017). Increasing connectivity between isolated vegetation patches is a major conservation strategy to reduce the negative effect of habitat fragmentation (Hodgson et al 2011). Nevertheless, increasing effective dispersal of seeds or pollen among patches (functional connectivity) is not always possible by just increasing structural connectivity, e.g. establishing landscape corridors, because the availability of dispersal vectors or recruitment microsites are needed to sustain functional connectivity (Auffret et al. 2017, Plue et al 2019).

Dispersal is a central life-history trait that structures the properties of ecosystems (Bonte \& Dahirel 2017; Massol et al. 2017). Particularly among fragmented natural habitats, dispersal is a key element for reducing extinction risk, and is subjected to strong selective pressures (Cheptou et al. 2017). Indeed, forecasts for the ongoing climate change include a massive rearrangement of species distributions, which could track their climate niches only if their dispersal is not impeded. In this context, livestock-mediated seed dispersal is an important vector for increasing functional connectivity. While the ecological importance of large wild herbivores is practically disappearing at the global scale (Ripple et al. 2014; Smith \& Botha-Brink 2014; Bar-On et al 2018), as are the migratory systems they support (Berger 2004), domestic herbivores have 
73 largely overtaken their role to the point that they can even substitute extinct megaherbivores

74 (Pires et al. 2014). The effectiveness of livestock seed dispersal as a cheap and effective

75 management tool for increasing connectivity between isolated grassland habitat patches has been

76 extensively surveyed (Cosyns et al. 2005; Couvreur et al. 2005; Auffret et al 2012; Emmerson et

77 al 2012), showing that the complementarity between different modes of dispersal (endo- and

78 epizoochory) can lead to an almost complete representation of the grassland community in the

79 dispersal spectra (Couvreur et al. 2005). Herbivory, trampling and nutrient redistribution by

80 livestock also generate microsites favorable to the recruitment of many adapted species (Bullock

81 et al 1994, Olff \& Ritchie, 1998), contributing to functional connectivity. Unfortunately,

82 livestock management is changing in many regions of the world for economic and social reasons,

83 and practices such as transhumance and rotational grazing are declining (Poschlod et al 1998,

84 Olea \& Mateo Tomás 2009, Auffret et al 2015).

85

86

87

88

89

90

91

92

93

94

95

96

97

Drove roads - routes traditionally used for mobile pastoralist livestock in many regions of the world - become particularly interesting to promote functional connectivity between isolated grasslands. Historic ones are presumed to often derive from ancient migratory routes of wildlife (Manzano Baena \& Casas 2010) Drove roads have been observed to have a strong effect in increasing multifunctionality of the landscape by working as linear grasslands and increasing heterogeneity at the large scale, translating into an increase of biodiversity in diverse taxonomic groups such as plants (Azcárate et al. 2013a), ants (Azcárate et al. 2013b; Hevia et al. 2013) or even bees, linked with important pollination services (Hevia et al. 2016). Given the proven capacity of livestock in achieving long-distance dispersal along drove roads, both by endozoochory (Manzano et al. 2005) and by epizoochory (Manzano \& Malo 2006), mobile pastoralism taking place in drove roads could potentially mitigate the consequences of population isolation, which is a major outcome of fragmentation processes (Fahrig 2003; Mitchell et al. 2015), especially in a grassland context (Pretelli et al 2018).

Dispersal is a multi-faceted process where the quantification of every step implies complex measurements that can result in great uncertainties at the landscape scale (Wang \& Smith 2002), and estimating its effective footprint is much more feasible through genetic analyses. Also, the study of the genetic structure and the gene flow between populations are essential to assess their viability in the long term. Fragmentation by isolation leaves a measurable genetic trace (Leblois et al. 2006). With such background, studies in livestock-grazed rangelands have observed that grazed areas display a more homogeneous genetic structure than ungrazed ones (Smith et al. 2009) and a less-than-expected population differentiation in Anthyllis vulneraria fragments historically subjected to rotational grazing (Honnay et al. 2006). Willerding \& Poschlod (2002) were unable to see effects of herd mobility in a rotational context, possibly due to the election of the target species (the anemophilous Bromus erectus). More recently, however, rotational grazing livestock has been observed to genetically link island grassland communities of Campanula rotundifolia that are otherwise isolated (Plue et al 2019). Similarly, livestock herded by foot from patch to patch in a rotation scheme has shown to be strong enough to leave a measurable trace in plant populations according to the distance covered, reducing genetic structure and increasing the viability of re-introduced grassland plants for Dianthus carthusianorum (Rico et al 2014a, Rico et al 2014b, Rico \& Wagner 2016) and Pulsatilla vulgaris (DiLeo et al 2017). While these results highlight the role of livestock as an effective and determinant vector for gene flow across the landscape, the artificial, network-like management of 
119

120

121

122

123

124

125

126

127

128

129

130

131

132

133

134

135

136

137

138

139

140

141

142

143

144

145

146

147

148

149

150

151

152

153

154

155

156

157

158

159

160

161

162

163

164

rotational grazing differs from the more corridor-like type of dispersal that is expected from wild migratory herbivores (Berger 2004), with bigger herds, longer distance migrated, shorter transit time per grassland area unit, and routes maintained during centuries, and which is mimicked by transhumant livestock (Manzano Baena \& Casas 2010). This perspective is even more relevant considering how widespread transhumance is worldwide, and how livestock can potentially substitute the ecological functions of wild migratory herbivores.

There are other important gene flow vectors beyond seed dispersal, however. Pollen flow also depends on landscape connectivity, where the structural features of the landscape that harbors pollinator communities (Auffret et al 2017) are more relevant for it than the existence of functional seed-dispersal vectors. This is a factor that seems especially relevant for fragmented agricultural landscapes crossed by livestock corridors, as the latter are reported to harbor a significant pollinator community (Hevia et al 2016). Wind pollination in angiosperms seems to have evolved in cases where biotic pollinators are limited (Culley et al 2002) and long-distance flow would be achieved in less common cases of high wind turbulence and speed, both very dependent on topography (Auffret et al 2017). Persistent seed banks can also alter the effects observed in the genetic structure of plant populations, particularly by delaying or mitigating the effects of fragmentation (Honnay et al 2008, Plue et al 2017).

In this study, we aimed to check whether dispersal processes in drove roads subjected to active use influence the population genetic structure of Plantago lagopus, an annual selfing plant species dispersed by livestock endo- and epizoochory along Spanish drove roads. These populations were located along the Conquense Drove Road (hereafter CDR; Figure 1) in Spain, one of the few drove roads under continuous use since (at least) the Middle Ages until even after the post-industrialization crisis of Spanish transhumance (Manzano Baena \& Casas 2010). The CDR connects isolated grasslands inserted in the surrounding agricultural matrix, which act as excellent controls to check for effects of transhumance on landscape connectivity between plant populations. Under this scenario, a landscape genetics approach provides excellent tools to evaluate the effects of anthropogenic factors over the populations of Plantago lagopus. In particular, we asked i) Is the CDR activity influencing gene flow among populations? ii) Do the populations in the CDR have similar genetic diversity and/or inbreeding values than those located in the agricultural matrix? and iii) Can other landscape factors (e.g. distance to human settlements, grasslands neighboring the drove road, time since last plowing) modify the genetic structure of the $P$. lagopus populations?

\section{MATERIALS \& METHODS}

\section{Studied species}

Plantago lagopus L. (Plantaginaceae) is a diploid polycarpic annual or biennial forb, abundant in grazed annual-dominated pastures of Central Spain (Peco et al. 2005). This species presents a persistent soil seed bank (Peco et al. 2003), gynodioecous breeding system and its seeds are dispersed by cattle endozoochory (Malo \& Suárez 1995). By sheep and under field conditions, epizoochoric dispersal is anecdotal, but endozoochory figures range from 3-7 seeds per g dry weight of manure in late spring when dispersal is highest and flocks are moving northwards, to 0.1 seeds in autumn when flocks are moving southwards (P Manzano, 2004-2006, personal 
165

166

167

168

169

170

171

172

173

174

175

176

177

178

179

180

181

182

183

184

185

186

187

188

189

190

191

192

193

194

195

196

197

198

199

200

201

202

203

204

205

206

207

208

209

210

observations). This translates into ca. 2 million P.lagopus seeds moved northward per transhumance day, or 50,000 seeds moved southward, for a typical flock of 1,000 sheep. Experiments have also shown seeds are largely viable after sheep ingestion (Peco et al. 2006) and remain attached for a long time on sheep coats (de Pablos \& Peco 2007), even under real transhumance conditions (Manzano \& Malo 2006). This species is self-compatible, with both wind and insects as major pollination agents (Sharma et al. 1993). Annual-dominated pastures in Central Spain are known to present particularly high diaspore availability related to summer drought but translated into massive dispersal by livestock, particularly at the time when transhumant herds are on the move (Manzano 2015a). Such large dispersal, along with the faster dynamics in annual plants (overlapping generations in perennial plants may disturb some genetic descriptors due to the mixture of genotypes), make them particularly suited to test genetic signals of dispersal in fragmented scenarios (Ewers \& Didham 2006).

\section{Landscape scenario and population sampling}

The study area is located between Quintanar de la Orden, Tomelloso and Villarrobledo municipalities in Castilla-La Mancha, Spain (coordinates: $39^{\circ} 18^{\prime} 03.17^{\prime \prime} \mathrm{N}$ and $2^{\circ} 49^{\prime} 54.50^{\prime \prime}$ W, Figure 1). The area is a plateau (830-900 meters a.s.l.) of sandstones, loams and clay materials under continental Mediterranean climate, with a mean annual rainfall of about $500 \mathrm{~mm}$ and severe summer droughts. The vegetation is a mosaic of agricultural dry cereal and sunflower croplands, abandoned fields and dry grasslands used by local flocks. The area is crossed by the Conquense Drove Road (CDR), one of the major road droves (ca. $410 \mathrm{~km}$ long) that are still used for transhumant sheep and cattle herds that move every year from the cooler and wetter mountains of Teruel, Cuenca and Guadalajara provinces to the wintering dehesas in Sierra Morena at lower altitude (Oteros-Rozas et al. 2012). The herds cross the study area twice a year (northwards in June and southwards in November), currently comprising about 9,000 heads of sheep and 1,200 of cattle. The size of transhumant herds, dominated by merino sheep, has shrunk from about half a million in the $16^{\text {th }}$ and $17^{\text {th }}$ centuries to $100,000-200,000$ in the next two centuries and around 20,000 during the second half of the $20^{\text {th }}$ century (Bacaicoa Salaverri et al. 1993). Productivity of the area is low except for peaks in May and October, because of cold winters and hot dry summers. Consequently, the numbers of transiting nomadic livestock have been historically much higher than those of resident livestock (Manzano Baena \& Casas 2010), which only grew in the last centuries (Bacaicoa Salaverri et al. 1993). Such resident livestock herds are, in turn, kept at stables in urban settlements at night and graze grassland patches that are spread across the landscape (Figure 1), overwhelmingly under private tenure. They graze mostly during wetter times in spring and autumn, the time of the year when local vegetation is growing (cf. Manzanares town in Manzano Baena \& Casas 2010) and diaspore availability is very low - in spring because plants have not yet produced seeds, and in autumn because rains incorporate the dead plant matter and any remaining diaspores into the soil. At other times of the year they are supplemented with hay, concentrate and water. Drove roads tend to avoid urban settlements and run rather tangentially (Figure 1), so resident livestock do little use of them because of the rather radial pattern of land use, with urban settlements in the center. As a result, management of local resident livestock is likely to have some effect on pollen flow because of available pastures and to cause some short-distance dispersal across them, but it is not likely to have effects on long-distance seed dispersal along the drove roads.

Peerj reviewing PDF | (2018:09:31235:2:0:NEW 6 Jun 2019) 
211 In winter 2013 we selected 13 populations of $P$. lagopus (6 in the CDR and 7 in isolated pastures 212 interspersed in the agricultural matrix). Populations located in the agricultural matrix were 213 located at least $5 \mathrm{~km}$ from the CDR. Each population consisted in a group of plants not further 214 than $100 \mathrm{~m}$ from each other, and all populations were at least $5 \mathrm{~km}$ apart from each other (Figure 215 1, Table 1). In each population, we randomly collected between 8 and 30 flowering individuals 216 of $P$. lagopus, whose leaves were stored under dry conditions until DNA extraction. Sampling 217 was done without prior permission, in accordance with article $32 \mathrm{~d}$ of the regional regulating law 218 on drove roads regarding common complementary uses, including educational and formative 219 activities in the environmental and cultural fields (Junta de Comunidades de Castilla la Mancha

220

221

222

223

224

225

226

227

228

229

230

231

232

233

234

235

236

237

238

239

240

241

242

243

244

245

246

247

248

249

250

251

252

253

254

255

256 2003). Authorization is required for such activities when they threaten the protection of sensitive ecosystem, forests with high wildfire risk, and protected flora and fauna species, and infringements are foreseen in its article 41 - but our sampling in the ecosystem was negligible, and P. lagopus is neither an endangered nor a protected species. We deposited five individuals at Real Jardín Botanico de Madrid - CSIC herbarium (reference numbers MA-01-00892341 to MA-01-00892345).

To test for the potential effect of other landscape factors on genetic descriptors, we measured the euclidean distance from the sampling points to the nearest human settlement using Google Maps. At the agricultural matrix points, we also checked the time since last plowing by inspecting historic aerial photographs from the area (Instituto Geográfico Nacional, Spain) - the oldest of which being 70 years old. The Conquense Drove Road, as in the case of all other major drove roads in Spain, has been protected from plowing for the last centuries (Bacaicoa Salaverri et al. 1993).

\section{Microsatellite development and laboratory protocols}

We developed specific microsatellite markers for P. lagopus in collaboration with the Unidad de Genómica, Parque Científico de Madrid (http://fpcm.es/en/servicios-cientificos/). Briefly, the library was developed from DNA of five individuals of $P$. lagopus extracted using QIAGEN plant Extraction Kit, using manufacturer's protocol. DNA was fragmented with ultrasounds using Bioruptor (Diagenode) and size fragment was selected for an approximated size of 1,2 kb. DNA sequencing was performed using a 454-FLX-Plus Roche sequencer. We obtained approximately 185000 sequences. We used Pal_Finder to select those sequences with more than 5 repetition motifs and a size that ranged from 100 to $300 \mathrm{bp}$. We used Primer3 (Untergasser et al. 2012) to configure potential primers that amplify those microsatellite regions. Details of the primers used are shown in Table S1.

\section{Genetic descriptors: diversity, Inbreeding, differentiation and structure}

We checked the six microsatellites used for genetic errors and misidentifications of alleles with Micro-checker (van Oosterhout et al, 2004). We estimated four genetic diversity indices:

observed and expected heterocigosity $\left(H_{O}\right.$ and $\left.H_{E}\right)$ using INEST 2.1 (Chybicki \& Burczyk 2009), the Shannon Information Index (I), as a measure of genetic diversity that considers the number of alleles and its dominance in the population and the number of private alleles $\left(A_{P}\right)$ using GeneAlEx 6.5 (Peakall \& Smouse 2012). Because the number of sampled individuals is different in each population (ranging from 8 to 30 , Table 1), we also calculated the genetic diversity using 
257 Hp-Rare (Kalinowski 2005) to rarefact the allelic richness and the number of private alleles to 258 the minimum number of individuals sampled in one population (i.e. 8 individuals) for better 259 comparisons between populations according to population size, hereafter $A_{\mathrm{r}}$ and PrivRare,

260

261

262

263

264

265

266

267

268

269

270

271

272

273

274

275

276

277

278

279

280

281

282

283

284

285

286

287

288

289

290

291

292

293

294

295

296

297

298

299

300

301 respectively. Linkage disequilibrium among loci was assessed with GenAlEx 6.5 (Peakall \& Smouse 2012).

We calculated the inbreeding coefficient, $F_{I S}$, using INEST 2.1. (Chybicki \& Burczyk 2009) that corrects the effect of null alleles, inbreeding and genotyping failures. DIC values between models with and without inbreeding were compared to evaluate the effect of inbreeding over $F_{I S}$. Departure from Hardy-Weinberg equilibrium with GeneAlEx 6.5 (Peakall \& Smouse 2012) to evaluate the inbreeding status of P. lagopus populations. We also assessed the presence of genetic bottlenecks generated by population dynamics (e.g. colonization events, population size reduction) using Bottleneck 1.2.02 (Piry et al. 1999), through a Wilcoxon test with 2000 permutations under the three plausible mutations models, as recommended for microsatellite data. We applied Bonferroni correction for multiple testing.

We estimated genetic differentiation with $\mathrm{F}_{\mathrm{ST}}$ coefficient calculated with FreeNA (Chapuis \& Estoup 2006) to minimize potential biases caused by null alleles or allele dropout. We tested signification between each pair of populations with 999 permutations. We used HIERFSTAT 0.04 (Goudet 2005) to evaluate the F-statistics grouping of the populations according to their location (either within the matrix or in the drove road) with 1000 permutations. To assess the presence of Isolation-by-Distance patterns, we performed a Mantel test with 999 permutations using genetic differentiation, (i.e. $\mathrm{F}_{\mathrm{ST}}$ coefficients) and Euclidean geographical distance between populations with Vegan package in R (Oksanen et al. 2007). Mantel tests were also developed considering the location of the populations (Drove Road or Matrix) with the same permutations. Genetic differentiation between patches was compared with the calculation of migration rates or number of migrants. BayesAss (Wilson \& Rannala 2003) and Migrate (Beerli 2009) were used to estimate recent and past migration rates respectively, using the default parameters recommended by the manual. This might show differences among ancestral or recent gene flow, given the progressive decrease of livestock movement along the drove road during the last decades. Mantel tests were also developed considering the location of the populations (Drove Road or Matrix) with the same permutations.

We assessed genetic structure using the Bayesian clustering method STRUCTURE v. 2.3.4 (Hubisz et al. 2009) with prior information on populations. We carried out 10 independent runs for each $K$ value (i.e. number of groups or clusters), ranging from 1 to 15 . Each run comprises a burning period of 100,000 permutations, followed by 1,000,000 MCMC (Markov Chain Monte Carlos) iterations. We assumed correlated allele frequencies and genetic admixture. To assess the most plausible number of clusters $(K)$, we used the STRUCTURESelector module (Li \& Liu 2018 ) to obtain plausible values of $K$. We considered the Evanno method (Evanno et al. 2005) with the ad hoc statistic $\Delta K$ and identified the maximum $\Delta K$ when plotted against $K$. MedMeaK (median of means), MedMedK (median of medians), MaxMeaK (maximum of means) and MaxMedK (maximum of medians) following Puechmaille (2016) were also estimated (threshold value $=0.6)$. These estimators are useful to discard spurious clusters and detect substructure in case of uneven sampling (Puechmaille 2016). We also used Clump v.1.1.2 (Jakobsson \& 
302 Rosenberg 2007) to estimate the membership coefficient of each individual in each cluster and

303 Distruct v 1.1 (Rosenberg 2004).

304

305

306

307

308

309

310

311

312

313

314

315

316

317

318

319

320

321

322

323

324

325

326

327

328

329

330

331

332

333

334

335

336

337

338

339

340

341

Relationships of genetic descriptors with environmental factors

To assess whether movement of transhumant herds along the drove road leaves a footprint, we selected the genetic descriptors that have most commonly been used previously in similar studies, i.e. $F_{I S}$ and $\mathrm{A}_{\mathrm{r}}$ (Rico et al 2014a, Rico et al 2014b, Rico \& Wagner 2016, DiLeo et al 2017, Plue et al 2019). We built multiple linear models fitted with generalized least squares ( $g l s$ function, nlme R-package) to examine the relationship between genetic diversity metrics with the population location (agricultural matrix or drove roads), the distance to nearby human settlements (in $\mathrm{km}$ ) and the interaction location $\mathrm{x}$ distance.

Due to the effect of pollinators activity to crossing system (i.e. selfing, partial selfing or outcrossing, Turner et al 1982, Dutech et al. 2005, Van Etten et al 2015), for the analysis of $F_{I S}$ the amount of grasslands in 500-m radius circles centered in sampling points (in percentage, logtransformed to achieve normality) was also included. The landscape descriptors (distance and percentage of grasslands) were standardized and centered to interpret model coefficients as standardized effects. Spatial autocorrelation was taken into account by building the GLS models with three alternative spatial covariance structures most commonly used to describe spatial correlation (Gaussian, Exponential and Spherical). The presence of nearby grasslands was included for the analysis of $F_{I S}$. This genetic descriptor is considered to be particularly influenced by pollinator activity, due to its effect over selfing and/or kinship crosses (Rico et al 2014b). Long-distance seed dispersal will rather happen along drove roads and through transhumant livestock that bypass such nearby grasslands, because the resident livestock that use them tend to have short-distance movements around human settlements and do not use the drove roads that run rather tangential to the settlements.

The differences in genetic diversity among populations may show a nested pattern suggesting that former connections between them have been lost (Aggemyr \& Cousins, 2012; Plue et al 2019). Nestedness appears when the set of alleles in communities with lower genetic diversity are a subset of those found in communities with higher genetic diversity, which would imply a deterministic loss of alleles. Thus, we explored whether such nested patterns occurred among our study populations and if they could be linked to the presence of the drove road, the distance to settlements and the amount of neighboring grasslands. If nestedness among populations is caused by loss of connectivity, we expect sites within the agricultural matrix and far from settlements to have lower allelic richness, lacking some particular alleles present in the populations of the drove road (in other words, sites within the agricultural matrix would have a higher degree of nestedness). Neighboring grasslands could act as a local source of propagules (seed and pollen) deterring the loss of alleles, and thus the larger the availability of neighboring grasslands the less likely we would find nestedness patterns. To describe nestedness patterns we used the NODF index (Almeida-Neto et al 2008). We tested if nestedness with a suitable null model based on 344 499 randomized matrices (null model ' $\mathrm{r} 2$ ' with package vegan in $\mathrm{R}$ which constrains row totals allelic richness - to equal the observed distribution and samples columns -alleles - with probability proportional to squared incidence frequencies). Then, we modeled the population rank order, from the highest rank of the population with most alleles to the lowest rank of the 
348

349

350

351

352

353

354

355

356

357

358

359

360

361

362

363

364

365

366

367

368

369

370

371

372

373

374

375

376

377

378

379

380

381

382

383

384

385

386

387

388

389

390

391

392

393

population with least alleles, with linear models built with generalized least squares as above. The populations differed in the number of individuals analyzed. Then, to balance sampling effort among them we repeated 50 times the above procedure, by randomly selecting the same number of individuals per population. Final NODF, p-values and rank estimates were the mean of the above procedure for these 50 balanced replicates.

For the three genetic diversity metrics $\left(F_{\text {IS }}\right.$ and $\left.\mathrm{A}_{\mathrm{r}}\right)$ and for nestedness, we did not try to simplify the models but identify the relevant predictors with p-values based on nested log-likelihood ratio tests. The genetic descriptors we used as response variables in the models were the inbreeding coefficient $\left(F_{\text {IS }}\right)$, the genetic diversity statistic $\left(\mathrm{A}_{\mathrm{r}}\right)$ and the nestedness estimates. We confirmed nearby grasslands to be only a relevant factor for $F_{\text {IS }}$ by comparing models of the three metrics with and without the grassland factor via AICc. Additionally, we tested the correlation of the genetic descriptors with the plowing history (years since last plowing) with base $\mathrm{R}$ and Anova function, car package and just for the populations in the agricultural matrix - the drove road has been protected from plowing for the last centuries.

\section{RESULTS}

\section{Genetic diversity and inbreeding}

The values for genetic diversity $\left(I, A_{P}, H_{O}, H_{E}, \mathrm{~A}_{\mathrm{r}}\right.$ and PrivRare) were similar between populations in the agricultural matrix and populations in the drove road, except for $A_{P}$, which was greater in the populations of the agricultural matrix, due to the large number of alleles found in LMA08 (Table 1). The average (CV) expected heterozygosity $H_{E}$ was $0.88(0.02)$ in drove roads populations and $0.89(0.03)$ in matrix populations. However, matrix populations showed greater variability in $H_{E}$, with values ranging from 0.92 in LMA13 to 0.84 in LMA08. The same pattern (similar average but different variability) was found in the other genetic diversity indexes (Table 1).

The inbreeding coefficient $\left(F_{\mathrm{IS}}\right)$ varied greatly among populations and between matrix and drove road locations. Drove road populations showed a mean value of 0.08 (ranging from 0.01 in LCR04 to 0.17 in LCR01), while matrix populations showed a mean value of 0.11 ranging from 0.06 in LMA05 to 0.17 in LMA14 (Table 1). Inbreeding had an important effect over Fis in LCR01, LMA11, LMA14 and LMA16 populations according to INEST model estimation. All populations had, at least, one locus that deviated from Hardy-Weinberg (HW) equilibrium (four loci in LCR01). Bottleneck signals were found in some populations under SMM model (LCR09, LMA08 and LMA11), but the results were not significant in all genetic models and applying multi-comparisons corrections (Table 2). Linkage disequilibrium among loci showed only four significant comparisons, which were non consistent between loci pairs.

\section{Genetic differentiation and structure}

Pairwise genetic differentiation values $\left(F_{S T}\right)$ between populations were low (Table S2). On average, LMA14 showed the greatest differentiation, with an average $F_{S T}$ value of 0.08 . 
394 Hierarchical analysis of the genetic differentiation showed low differentiation between matrix 395 and drove road locations $\left(F_{C T}=0.032\right)$ and a moderate one between populations within each 396 category $\left(F_{S C}=0.11\right)$. Both values are significant. Mantel test $(r=0.13 ; p=0.22)$ did not detect 397 the presence of an isolation-by-distance (IBD) pattern, but results were significant when only 398 analyzing the six populations included in the drove road $(r=1 ; p<0.01)$. The genetic structure

399

400

401

402

403

404

405

406

407

408

409

410

411

412

413

414

415

416

417

418

419

420

421

422

423

424

425

426

427

428

429

430

431

432

433

434

435

436

437

438

439

440 analyzed with a Bayesian clustering approach (i.e. STRUCTURE, Figure 2) showed different values depending of the approach consider to estimated $K$. The estimation of $\Delta K$ proposed values of $K=12$ and $K=4$ as more plausible approaches. MedMedK, MedMeanK and MaxMaxK also pinpoint that $K=4$ is the most appropriated distribution of the genetic structure and MaxMedK suggested that $\mathrm{K}=5$ is the most accurate result. The $K=4$ distribution showed an independent cluster (green) for LMA14 population, another cluster (purple) for LMA16, LMA13 and LCR10 populations and a third cluster (orange). The other populations are assigned to the last cluster, with admixture of the others. The $K=12$ distribution showed an important population admixture and one cluster assigned to LMA14 population (Figure 2). The results for gene flow (BayesAss and Migrate, Table 3, Figure 3) showed differences for the migration rates estimated, with higher values for past gene flow (i.e. Migrate) than contemporary (i.e BayesAss). The evaluation of the recent gene flow (i.e. BayesAss), focus the main differences in the population LMA08 that received a significant number of migrants and in lesser extent, LMA16 and LCR01. The remaining populations showed similar migrations rates between populations. The ancient gene flow analyzed (i.e. Migrate) showed similar mean values for drove roads and matrix populations but important differences between populations. Although LMA08 maintains high values of gene flow, LCR02 received the highest average migration rate meanwhile LCR10 showed the smallest average value.

\section{Landscape factors governing genetic descriptors in P. lagopus populations}

The distance to the nearest settlement had an impact on both genetic descriptors analyzed (Table 4). This relationship is independent of the frequency of plowing, because for the agricultural matrix plots the correlations of years since last plowing and the residuals of the regressions explaining the genetic descriptors were non-significant. Also, the values of genetic descriptors did not correlate significantly with the number of years since last plowing (Pearson correlations were $0.07, \mathrm{p}=0.89$ for $F_{I S}$; and $-0.13, \mathrm{p}=0.78$ for $\mathrm{A}_{\mathrm{r}}$ ).

In addition to the distance to the nearest settlement, the interaction with population position showed a significant effect on inbreeding $\left(F_{I S}\right.$; Table 4$)$. Thus, $F_{I S}$ increased with distance from human settlements in the agricultural matrix, but followed the opposite trend in drove road populations (Figure 4a). The presence of nearby grasslands also proved to be a significant factor, showing higher rates of inbreeding at higher grassland cover (Table 4).

For the descriptor of genetic diversity $\left(\mathrm{A}_{\mathrm{r}}\right)$, the distance to settlements had a consistent negative and significant effect, while the effect for population position and its interaction with distance was only marginally significant (Table 4 ). A $A_{r}$ values between matrix and drove road positions showed a pattern of convergence at short distances and divergence at high distances from human settlements, with the agricultural matrix then showing less diversity (Figure 4b).

Significant nestedness was found among the Plantago lagopus populations (mean observed $\mathrm{NODF}=34.7$, mean $\mathrm{p}$-value $=0.02$, all averaged from 50 random selections of individuals to 
441 balance sample size among populations). None of the geographic parameters, however,

442 significantly affected the rank (Table 4).

443

444

445

446

447

448

449

450

451

452

453

454

455

456

457

458

459

460

461

462

463

464

465

466

467

468

469

470

471

472

473

474

475

476

477

478

479

480

481

482

483

484

485

486

\section{DISCUSSION}

Drove roads have a significant capacity to shape some genetic features of Plantago lagopus populations in the study area. This assessment of the population genetics of $P$. lagopus in the study area indicates relevant differences both in terms of coefficient of inbreeding and of genetic diversity between populations and between matrix and drove roads positions. Furthermore, proximity to human settlements appeared to drive the hotspots for genetic diversity in this landscape. Drove roads were able to invert the inbreeding that otherwise appears in distant populations from the agricultural matrix. The loss in genetic diversity with increasing distance to human settlements seems weaker at drove roads, although such effect is only marginally significant with the sample size and the molecular markers used in this study. Such a trend would, however, be in line with the one that was observed by other studies involving livestock being moved on hoof (Rico et al 2014a, Rico \& Wagner 2016, DiLeo et al 2017), as well as by more artificial transport (boat; Plue et al 2019). The higher estimated migration rates for past events compared to contemporary ones would confirm the declining influence of transhumance in the landscape as transhumant livestock numbers continue to decline. An influence of historical processes of colonization can be discarded, due to the absent effect that plowing history had both on inbreeding and diversity on the populations from the agricultural matrix - the time span considered for plowing history, i.e. 70 years, should also allow for controlling delay effects related to the establishment of a permanent seed bank as discussed by Honnay et al (2008) and Plue et al (2017), of which P. lagopus is capable.

In a self-compatible plant species pollinated both by wind and by insects, such as $P$. lagopus, population inbreeding is mainly determined by the ratio between selfing and outcrossing, where outcrossing is enhanced by pollinator availability. Thus, the smaller selfing coefficient and the reduced influence over $F_{I S}$ observed along the drove road indicates a relevant role played by them in providing pollination services. This relationship is even clearer after controlling for landscape effects, namely the presence of grassland patches in the vicinity of the studied plant populations that could harbor further pollinators. In fact, we found the same potential negative relationship between the presence of such patches and the pollinators, mirroring the results of Rico et al (2014b) and, similarly to the potential explanation there, it could rely on the flowering plants on such patches being continuously grazed during the whole spring by resident sheep flocks. Meanwhile, the transhumant herds graze on the drove road only at the end of the spring, following a "green wave" when the plants have already grained, relatively untouched during the flowering phase. While a greater coefficient of inbreeding is a genetic indicator that can be related to pollinator limitation (Turner et al 1982, Dutech et al. 2005, Van Etten et al. 2015), the structural role of drove roads as grassland corridors crossing agricultural landscapes has been proved to be determinant in supporting pollinator services (Hevia et al. 2016), which our study confirms. This result goes along other studies that have observed provision of heterogeneity at the landscape level because of the drove road's structural role, translated in higher biodiversity levels (Azcárate et al. 2013a; Hevia et al. 2013). Plowing does not show any effect or trend on the genetic variables studied, suggesting that structural continuity in space is more important than stability in time to guarantee genetic admixture. 
487 Distance to human settlements showed a consistent effect on genetic diversity and inbreeding. 488 The resulting functional landscape can be interpreted as settled, high human density areas being 489 hotspots of dispersal that modulate the genetic patterns of diversity, probably mediated by 490 commercial livestock exchanges but also by other dispersal types, mainly human-mediated 491 (Auffret 2011; Auffret \& Cousins 2013; Wichmann et al. 2009). The P. lagopus populations on 492 the drove road don't show to be affected by these types of dispersal, likely because their human 493 use is much diluted and human activities are comparatively simplified and less dense, consisting just in accompanying or herding livestock. They also show to be pollinator reserves with a higher relevance than peri-urban grassland patches. Such important role played by human settlements for seed dispersal is not surprising, given that human-mediated dispersal adds to livestockmediated dispersal mechanisms (Auffret 2011; Auffret \& Cousins 2013) which are problematic for the spread of invasive species (Abbas et al. 2018). However, it offers insights on how an unnatural over-dispersal that facilitates invasiveness of some plant species (Wilson et al. 2009) may be visible already at small geographical scales such as the one regarded in this study. Genetic analyses that further explore the role of livestock or other dispersal vectors may offer valuable insights on the ecology of potential or confirmed invasive species, especially in relationship with their human-mediated dispersal.

The trend of a higher genetic diversity on drove roads compared to the agricultural matrix (Figure 4b), even if only marginally significant and limited by the reduced sample size and the limited number of molecular markers, would be consistent with the determinant role of livestock as seed disperser at the genetic level that has been observed in other studies (Rico et al 2014a, Rico \& Wagner 2016, DiLeo et al 2017, Plue et al 2019). It may be pointing to a scenario where two types of dispersal processes coexist. On the one hand, populations in the agricultural matrix would receive seeds through the local stock through short-distance dispersal processes.

Meanwhile, long-distance dispersal processes favoring greater admixture dominate in the drove roads actively being used by livestock, therefore functioning as a highway for seeds. This would highlight the important role of active livestock movements for preserving the functionality of drove roads and, more generally, herbivore migration corridors. Such effects seem to be too weak to be perceived as significant, given our low sample size and reduced molecular markers used, on top of the moderate levels of gene flow that homogenize the genetic diversity between the populations. The observable trend and the estimated effects on past and current migration rates, however, may be pointing to a very promising area of research for future studies, especially considering that the long history of drove roads in Spain, with fixed ancient routes coinciding with older herbivore routes, may be showing a sustained contribution to long-distance seed dispersal (Manzano Baena \& Casas 2010; Manzano \& Malo 2006). Further insights on the persistence of effects may be gained by comparing the CDR with other Spanish drove roads abandoned in the mid-20 $0^{\text {th }}$ century (Manzano Baena \& Casas 2010).

\section{Implications for ecosystem function and conservation}

Functional herbivore corridors would sustain diversity by reducing the risk of local extinctions due to increased inbreeding and loss of genetic variation in small populations (Caughley 1994). The effect of drove roads on inbreeding observed in our study has relevant implications for conservation, as inbreeding depression is a major concern for the conservation of biodiversity in human-altered fragmented landscapes (Hedrick \& Garcia-Dorado 2016). We think that 
533 connectivity factors, related to herbivore type and capability of sustaining dispersal corridors for 534 plants, as well as optimal matching of grazing times with the flowering and seeding phenology of 535 plants, would therefore add to the complexity of factors that influence the relationship between 536 grazing and plant diversity. Such factors include productivity and disturbance (Herrero-Jáuregui 537 \& Oesterheld 2018; Olff \& Ritchie 1998), historical effects on communities (Cingolani et al. 538 2005; Osem et al. 2002) or herbivore species and sizes (Bakker et al. 2006; Liu et al. 2015).

539 Functional herbivore corridors would sustain diversity by reducing the risk of local extinctions 540 due to loss of genetic variation in small populations (Caughley 1994).

541

542

543

544

545

546

547

548

549

550

551

552

553

554

555

556

557

558

559

560

561

562

563

564

565

566

567

568

569

570

571

572

573

574

575

576

577

578

The marginally significant, yet observable trend of drove roads in reducing genetic diversity loss of $P$. lagopus, in spite of the rapid transit of transhumance flocks - ca. $15 \mathrm{~km} / \mathrm{day}$, or $1.5 \mathrm{~km} / \mathrm{h}$ when moving (Hevia et al. 2013) is very noteworthy. Such a use, which is intense but nevertheless very restricted in time, would achieve extraordinary dispersal effects due to a "green wave effect" (Merkle et al. 2016), as transhumant flocks use drove road pastures when they are at their maximum productivity (Manzano Baena \& Casas 2010) and therefore at their maximum seed production stage - which would add to the reduced impact on pollinators we observed that is also related to the "green wave effect". This is a radical contrast with other works studying rotational grazing systems (Rico et al 2014a, Rico et al 2014b, Rico \& Wagner 2016, DiLeo et al 2017, Plue et al 2019) where the intensity of use per unit of area is much higher and the chances for consolidating dispersal between patches are also higher, and the effects on pollinator community are less clear. Indeed, a confirmation of such trend in future studies that are able to study more populations than we did would highlight the potential role of herbivore corridors to promote long distance dispersal. The higher estimated migration rates in the past than in the present are also an alert on the negative effect that declining transhumant practices may have on ecosystems.

Mobile pastoralism is globally threatened by non-conductive policies (Manzano 2017), threatening its role as a provider of important ecosystem functions such as habitat provision, nutrient cycling, or bush encroachment/fire control (Leroy et al. 2018). The potential magnitude of the threat is great, for such land use covers more than half of the global land (Manzano 2015b). A derived disruption of dispersal processes and the structural role for pollinators played by corridors themselves may further contribute to a generalized grassland biodiversity crisis motivated by land use intensification (Gossner et al. 2016) and climate change - and on the latter, a potential decoupling of herbivore "green wave" movements from the phenology and seed availability brings also concerns (Berg et al. 2010; Thackeray et al. 2016). It is urgent to quantify such dispersal beyond our study in order to orient adequate science-evidenced policy recommendations (Manzano Baena 2012). Furthermore, corridors per se are important beyond livestock. We obtained our data in a drove road that has experienced a drastic decline in use in the recent centuries, from 600,000 head in the $16^{\text {th }}$ century to less than 10,000 nowadays (Bacaicoa Salaverri et al. 1993; Hevia et al. 2013). The effect on the genetics of plants must have been much more significant at that time, similar to what they must be in the systems presently steered by hundreds of millions of mobile pastoralists (Manzano \& Agarwal 2015), whose capacity to cover wide territories is shown by the fractal structure of their drove roads in different countries (Manzano-Baena \& Salguero-Herrera 2018). This effect should also be greater in the world's greatest wild herbivore migrations (Berger 2004). 


\section{CONCLUSIONS}

580 Our results are relevant for shaping conservation policies that take into account the role of 581 herbivores, be them wild or domestic. We confirm the relevance that herbivore corridors and

582

583

584

585

586

587

588

589

590

591

592

593

594

\section{5}

596

597

598

599

600

601

602

603

604

605

606

607

608

609

610

611

612

613

614

615

616

617

618

619

620

621

622

623 mobile pastoralism have in reducing inbreeding levels in plant populations, as well as their potential, within the possibilities of our limited data, in facilitating long-distance plant migration that has been envisioned in seed dispersal studies (Manzano et al 2005, Manzano \& Malo 2006). Such corridors may have to be kept in use in order to preserve full ecological functionality (Starrs 2018) that goes beyond their role as landscape structures. Their potential adds to the already identified needs to reduce fragmentation in the dryland areas occupied by pastoralists (Said et al 2016), and international conventions that deal with such issues (Durant et al. 2015). Some hotly debated national policies related to drove roads (AA.VV. 2012; Herzog et al. 2005) should as well take note on our results. We also highlight the interest of expanding such studies to other animal-dispersed species in order to quantify the importance of corridors for the maintenance of population genetic exchange levels in a world confronted with global change, and where deleterious effects on plant genetic diversity are already visible (Alsos et al. 2012).

\section{ACKNOWLEDGMENTS}

P. M. would like to thank F. Xavier Picó Mercader for an enlightening dinner conversation at the $2^{\text {nd }}$ Iberian Ecological Congress in July 2006 that was key to boost many of the ideas in this paper, as well as to Juan Orellana Saavedra and Raquel Casas Nogales for previous design attempts of this study. Juan Carlos Illera offered invaluable guidance during the initial stages of genetic analyses. Ricardo Ramos, Jesús García and Sara Álvarez from the genomic units at Cantoblanco and Moncloa of the Madrid Science Park (https://fpcm.es) provided the PCR and sequencing services with a great amount of flexibility.

\section{REFERENCES}

AA.VV. 2012. La trashumancia en España. Libro Blanco: Ministerio de Agricultura, Alimentación y Medio Ambiente.

Abbas AM, Mancilla-Leytón JM, and Castillo JM. 2018. Can camels disperse seeds of the invasive tree Prosopis juliflora? Weed Research 58:221-228. DOI: 10.1111/wre.12298

Aggemyr, E., \& Cousins, S. A. 2012. Landscape structure and land use history influence changes in island plant composition after 100 years. Journal of Biogeography, 39: 1645-1656. DOI: $10.1111 / \mathrm{j} .1365-2699.2012 .02733 . \mathrm{x}$

Almeida-Neto, M., Guimaraes, P., Guimaraes Jr, P. R., Loyola, R. D., \& Ulrich, W. 2008. A consistent metric for nestedness analysis in ecological systems: reconciling concept and measurement. Oikos, 117: 1227-1239. DOI: 10.1111/j.0030-1299.2008.16644.x.

Alsos IG, Ehrich D, Thuiller W, Eidesen PB, Tribsch A, Schönswetter P, Lagaye C, Taberlet P, and Brochmann C. 2012. Genetic consequences of climate change for northern plants. Proc R Soc B:rspb20112363. DOI: 10.1098/rspb.2011.2363

Auffret AG. 2011. Can seed dispersal by human activity play a useful role for the conservation of European grasslands? Applied Vegetation Science 14:291-303. DOI: 10.1111/j.1654109X.2011.01124.X

Auffret AG, Schmucki R, Reimark J, Cousins SAO. 2012. Grazing networks provide useful functional connectivity for plants in fragmented systems. Journal of Vegetation Science 23, 970-977. DOI: 10.1111/j.1654-1103.2012.01413.x 
624

625

626

627

628

629

630

631

632

633

634

635

636

637

638

639

640

641

642

643

644

645

646

647

648

649

650

651

652

653

654

655

656

657

658

659

660

661

662

663

664

665

666

667

668

669

Auffret AG, Cousins SAO. 2013. Grassland connectivity by motor vehicles and grazing livestock. Ecography 36, 1150-1157. DOI: 10.1111/j.1600-0587.2013.00185.x

Auffret AG, Plue J, and Cousins SAO. 2015. The spatial and temporal components of functional connectivity in fragmented landscapes. Ambio 44: 51-59. DOI: 10.1007/s13280-0140588-6

Auffret AG, Rico Y,, Bullock JM, Hooftman DAP, Pakeman RJ, Soons MB, Suárez-Esteban A, Traveset A, Wagner HH, and Cousins SAO. 2017. Plant functional connectivity integrating landscape structure and effective dispersal. Journal of Ecology 105: 16481656. DOI: $10.1111 / 1365-2745.12742$

Azcárate FM, Robleño I, Seoane J, Manzano P, and Peco B. 2013a. Drove roads as local biodiversity reservoirs: effects on landscape pattern and plant communities in a Mediterranean region. Applied Vegetation Science 16:480-490. DOI: 10.1111/avsc. 12003

Azcárate FM, Seoane J, Castro S, and Peco B. 2013b. Drove roads: Keystone structures that promote ant diversity in Mediterranean forest landscapes. Acta Oecologica 49:107-115. DOI: $10.1016 /$ j.actao.2013.03.011

Bacaicoa Salaverri I, Elías Pastor JM, and Grande Ibarra J. 1993. Cuadernos de la trashumancia. Albarracín-Cuenca - Molina: ICONA, Madrid, Spain.

Bakker ES, Ritchie ME, Olff H, Milchunas DG, and Knops JM. 2006. Herbivore impact on grassland plant diversity depends on habitat productivity and herbivore size. Ecology Letters 9:780-788. DOI: 10.1111/j.1461-0248.2006.00925.x

Bar-On YM, Phillips R, and Milo R. 2018. The biomass distribution on Earth. PNAS 115: 65066511. DOI:10.1073/pnas.1711842115

Beerli P. 2009. How to use MIGRATE or why are Markov chain Monte Carlo programs difficult to use. Population genetics for animal conservation 17:42-79. DOI: $10.1017 / \mathrm{CBO} 9780511626920.004$

Berg MP, Kiers ET, Driessen G, van der Heijden M, Kooi BW, Kuenen F, Liefting M, Verhoef HA, and Ellers J. 2010. Adapt or disperse: understanding species persistence in a changing world. Global Change Biology 16:587-598. DOI: 10.1111/j.13652486.2009.02014.x

Berger J. 2004. The last mile: how to sustain long-distance migration in mammals. Conservation Biology 18:320-331. DOI: 10.1111/j.1523-1739.2004.00548.x

Bonte D, and Dahirel M. 2017. Dispersal: a central and independent trait in life history. Oikos 126:472-479. DOI: 10.1111/oik.03801

Bullock JM, Hill BC, and Silvertown J. 1994. Demography of Cirsium vulgare in a grazing experiment. Journal of Ecology 82, 101-111. DOI: 10.2307/2261390

Caughley G. 1994. Directions in conservation biology. Journal of Animal Ecology 63:215-244. DOI: $10.2307 / 5542$

Cingolani AM, Noy-Meir I, and Díaz S. 2005. Grazing effects on rangeland diversity: a synthesis of contemporary models. Ecological Applications 15:757-773. DOI: 10.1890/03-5272

Cosyns E, Claerbout S, Lamoot I, and Hoffmann M. 2005. Endozoochorous seed dispersal by cattle and horse in a spatially heterogeneous landscape. Plant Ecology 178:149-162. DOI: $10.1007 / \mathrm{s} 11258-004-2846-3$

Couvreur M, Cosyns E, Hermy M, and Hoffmann M. 2005. Complementarity of epi-and endozoochory of plant seeds by free ranging donkeys. Ecography 28:37-48. DOI: 10.1111/j.0906-7590.2005.04159.x

Peerj reviewing PDF | (2018:09:31235:2:0:NEW 6 Jun 2019) 
670 Crutsinger GM, Collins MD, Fordyce JA, Gompert Z, Nice CC, and Sanders NJ. 2006. Plant 671 genotypic diversity predicts community structure and governs an ecosystem process.

672

673

674

675

676

677

678

679

680

681

682

683

684

685

686

687

688

689

690

691

692

693

694

695

696

697

698

699

700

701

702

703

704

705

706

707

708

709

710

711

712

713

714

715

Science 313:966-968. DOI: 10.1126/science.1128326

Chapuis M-P, and Estoup A. 2006. Microsatellite Null Alleles and Estimation of Population Differentiation. Mol Biol Evol:msl191. 10.1093/molbev/msl191 DOI: 10.1093/molbev/msl191

Cheptou P-O, Hargreaves AL, Bonte D, and Jacquemyn H. 2017. Adaptation to fragmentation: evolutionary dynamics driven by human influences. Phil Trans R Soc B 372:20160037. DOI: $10.1098 /$ rstb.2016.0037

Chybicki IJ, and Burczyk J. 2009. Simultaneous Estimation of Null Alleles and Inbreeding Coefficients. Journal of Heredity 100:106-113. DOI: 10.1093/jhered/esn088

Culley TM, Weller SG, and Sakai AK. 2002. The evolution of wind pollination in angiosperms. Trends in Ecology and Evolution 17: 361-369. DOI: 10.1016/S0169-5347(02)02540-5

de Pablos I, and Peco B. 2007. Diaspore morphology and the potential for attachment to animal coats in Mediterranean species: an experiment with sheep and cattle coats. Seed Science Research 17:109-114. DOI: 10.1017/S0960258507708097

DiLeo MF, Rico Y, Boehmer HJ, and Wagner HH. 2016. An ecological connectivity network maintains genetic diversity of a flagship wildflower, Pulsatilla vulgaris. Biological Conservation 212:12-21. DOI: 10.1016/j.biocon.2017.05.026

Durant SM, Becker MS, Creel S, Bashir S, Dickman AJ, Beudels-Jamar RC, Lichtenfeld L, Hilborn R, Wall J, and Wittemyer G. 2015. Developing fencing policies for dryland ecosystems. Journal of Applied Ecology 52:544-551. DOI: 10.1111/1365-2664.12415

Dutech C, Sork VL, Irwin AJ, Smouse PE, Davis FW. 2005. Gene flow and fine-scale genetic structure in a wind-pollinated tree species, Quercus lobata (Fagaceaee). American Journal of Botany 92: 252-261. DOI: 10.3732/ajb.92.2.252

Emmerson LM, Facelli JM, Chesson P, Possingham H, Day JR. 2012. Changes in seed dispersal processes and the potential forbetween-patch connectivity for an arid land daisy. Ecology 93, 544-553. DOI: 10.1890/11-0651.1

Evanno G, Regnaut S, and Goudet J. 2005. Detecting the number of clusters of individuals using the software STRUCTURE: a simulation study. Molecular Ecology 14:2611-2620. DOI: 10.1111/j.1365-294X.2005.02553.x

Ewers RM, and Didham RK. 2006. Confounding factors in the detection of species responses to habitat fragmentation. Biological Reviews 81:117-142. DOI: $10.1017 /$ S 1464793105006949

Fahrig L. 2003. Effects of habitat fragmentation on biodiversity. Annual Review of Ecology Evolution and Systematics 34:487-515. DOI: 10.1146/annurev.ecolsys.34.011802.132419

Gossner MM, Lewinsohn TM, Kahl T, Grassein F, Boch S, Prati D, Birkhofer K, Renner SC, Sikorski J, Wubet T, Arndt H, Baumgartner V, Blaser S, Blüthgen N, Börschig C, Buscot F, Diekötter T, Jorge LR, Jung K, Keyel AC, Klein A-M, Klemmer S, Krauss J, Lange M, Müller J, Overmann J, Pašalić E, Penone C, Perović DJ, Purschke O, Schall P, Socher SA, Sonnemann I, Tschapka M, Tscharntke T, Türke M, Venter PC, Weiner CN, Werner M, Wolters V, Wurst S, Westphal C, Fischer M, Weisser WW, and Eric Allan E. 2016. Land-use intensification causes multitrophic homogenization of grassland communities. Nature 540:266-269. DOI: 10.1038/nature20575

Goudet J. 2005. Hierfstat, a package for $\mathrm{R}$ to compute and test hierarchical F-statistics. Molecular Ecology Resources 5:184-186. DOI: 10.1111/j.1471-8286.2004.00828.x

Peer) reviewing PDF | (2018:09:31235:2:0:NEW 6 Jun 2019) 
716 Hedrick PW, and Garcia-Dorado A. 2016. Understanding inbreeding depression, purging, and 717 genetic rescue. Trends in Ecology \& Evolution 31:940-952. DOI:

718

719

720

721

722

723

724

725

726

727

728

729

730

731

732

733

734

735

736

737

738

739

740

741

742

743

744

745

746

747

748

749

750

751

752

753

754

755

756

757

758

759

10.1016/j.tree.2016.09.005

Herrero-Jáuregui C, and Oesterheld M. 2018. Effects of grazing intensity on plant richness and diversity: a meta-analysis. Oikos 127:757-766. DOI: 10.1111/oik.04893

Herzog F, Bunce RG, Pérez-Soba M, Jongman RH, Sal AG, and Austad I. 2005. Policy Options to Support Transhumance and Biodiversity in European Mountains: A Report on the TRANSHUMOUNT Stakeholder Workshop, Landquart/Zurich, Switzerland, 26-28 May 2004. Mountain Research and Development 25:82-84. DOI: 10.1659/02764741(2005)025[0082:POTSTA]2.0.CO;2

Hevia V, Azcárate FM, Oteros-Rozas E, and González JA. 2013. Exploring the role of transhumance drove roads on the conservation of ant diversity in Mediterranean agroecosystems. Biodiversity and Conservation 22:2567-2581. DOI: 10.1007/s10531013-0539-8

Hevia V, Bosch J, Azcárate FM, Fernández E, Rodrigo A, Barril-Graells H, and González JA. 2016. Bee diversity and abundance in a livestock drove road and its impact on pollination and seed set in adjacent sunflower fields. Agriculture, Ecosystems \& Environment 232:336-344. DOI: 10.1016/j.agee.2016.08.021

Hodgson JA, Moilanen A, Wintle BA, and Thomas CD. 2011. Habitat area, quality and connectivity: striking the balance for efficient conservation. Journal of Applied Ecology 48: 148-152. DOI: 10.1111/j.1365-2664.2010.01919.x

Honnay O, Coart E, Butaye J, Adriaens D, Van Glabeke S, and Roldán-Ruiz I. 2006. Low impact of present and historical landscape configuration on the genetics of fragmented Anthyllis vulneraria populations. Biological Conservation 127:411-419. DOI: 10.1016/j.biocon.2005.09.006

Honnay O, Bossuyt B, Jacquemyn H, Shimono A, and Kentaro Uchiyama. 2008. Can a seed bank maintain the genetic variation in the above ground plant population? Oikos 117: 1-5. DOI: $10.1111 / j .2007 .0030-1299.16188 . x$

Hubisz MJ, Falush D, Stephens M, and Pritchard JK. 2009. Inferring weak population structure with the assistance of sample group information. Molecular Ecology Resources 9:13221332. DOI: $10.1111 / \mathrm{j} .1755-0998.2009 .02591 . x$

Jakobsson M, and Rosenberg NA. 2007. CLUMPP: a cluster matching and permutation program for dealing with label switching and multimodality in analysis of population structure. Bioinformatics 23:1801-1806. DOI: 10.1093/bioinformatics/btm233

Junta de Comunidades de Castilla-La Mancha. 2003. Ley 9/2003, de 20-03-2003, de Vías Pecuarias de Castilla-La Mancha. DOCM 50, April $8^{\text {th }} 2003$ \& BOE 132, June $3^{\text {rd }} 2003$.

Kalinowski ST. 2005. HP-RARE 1.0: a computer program for performing rarefaction on measures of allelic richness. Molecular Ecology Notes 5:187-189. DOI: 10.1111/j.14718286.2004.00845.x

Leblois R, Estoup A, and Streiff R. 2006. Genetics of recent habitat contraction and reduction in population size: does isolation by distance matter? Molecular Ecology 15:3601-3615.

Leroy G, Hoffmann I, From T, Hiemstra S, and Gandini G. 2018. Perception of livestock ecosystem services in grazing areas. Animal 12:2627-2638. DOI: $10.1017 / \mathrm{S} 1751731118001027$

Peer) reviewing PDF | (2018:09:31235:2:0:NEW 6 Jun 2019) 
760

761

762

763

764

765

766

767

768

769

770

771

772

773

774

775

776

777

778

779

780

781

782

783

784

785

786

787

788

789

790

791

792

793

794

795

796

797

798

799

800

801

802

803

804

805
Li Y-L, and Liu J-X. 2018. StructureSelector: A web-based software to select and visualize the optimal number of clusters using multiple methods. Molecular Ecology Resources 18:176-177. DOI: 10.1111/1755-0998.12719

Liu J, Feng C, Wang D, Wang L, Wilsey BJ, and Zhong Z. 2015. Impacts of grazing by different large herbivores in grassland depend on plant species diversity. Journal of Applied Ecology 52:1053-1062. DOI: 10.1111/1365-2664.12456

Malo JE, and Suárez F. 1995. Herbivorous mammals as seed dispersers in a Mediterranean dehesa. Oecologia 104:246-255. DOI: 10.1007/BF00328589

Manzano P. 2015a. Transporte de semillas por las ovejas trashumantes, y sus potenciales implicaciones en la vegetación. D. Phil. Thesis, Universidad Autonoma de Madrid. Available at http://hdl.handle.net/10486/670899 (accessed 12 september 2018)

Manzano P. 2015b. Pastoralist Participation and Networking in Policy dialogue: Dimensions and Challenges. UNEP Perspectives 18:1-16. Available at http://hdl.handle.net/20.500.11822/10003 (accessed 12 september 2018)

Manzano P. 2017. Development interventions on pastoralist areas: a new decision matrix to identify win-win situations and no-go zones. The Solutions Journal 8. Available at https://tinyurl.com/ycf7xhry (accessed 12 september 2018)

Manzano P, Malo JE, and Peco B. 2005. Sheep gut passage and survival of Mediterranean shrub seeds. Seed Science Research 15:21-28. DOI: 10.1079/SSR2004192

Manzano P, and Malo JE. 2006. Extreme long-distance seed dispersal via sheep. Frontiers in Ecology and the Environment 4:244-248. DOI: 10.1890/15409295\%282006\%29004\%5B0244:ELSDVS\%5D2.0.CO;2

Manzano Baena P. 2012. Shaping policies: science-policy interface in natural resources management. In: Davies J, ed. Conservation and Sustainable Development. Ottawa: IDRC, 123-142.

Manzano Baena P, and Casas R. 2010. Past, present and future of transhumancia in Spain: Nomadism in a developed country. Pastoralism: research, policy and practice 1:72-90.

Manzano-Baena P, and Salguero-Herrera C. 2018. Mobile Pastoralism in the Mediterranean: Arguments and evidence for policy reform and to combat climate change. MCfNC, editor. Available at https://tinyurl.com/yalgh87o (accessed 12 september 2018)

Massol F, Altermatt F, Gounand I, Gravel D, Leibold MA, and Mouquet N. 2017. How life-history traits affect ecosystem properties: effects of dispersal in meta-ecosystems. Oikos 126:532-546. DOI: 10.1111/oik.03893

Matesanz S, Rubio Teso ML, García-Fernández A, and Escudero A. 2017. Habitat fragmentation differentially affects genetic variation, phenotypic plasticity and survival in populations of a gypsum endemic. Frontiers in Plant Science 8:843. DOI: 10.3389/fpls.2017.00843

Merkle JA, Monteith KL, Aikens EO, Hayes MM, Hersey KR, Middleton AD, Oates BA, Sawyer H, Scurlock BM, and Kauffman MJ. 2016. Large herbivores surf waves of greenup during spring. Proceedings of the Royal Society B: Biological Sciences 283. DOI: 10.1098/rspb.2016.0456

Mitchell MG, Suarez-Castro AF, Martinez-Harms M, Maron M, McAlpine C, Gaston KJ, Johansen K, and Rhodes JR. 2015. Reframing landscape fragmentation's effects on ecosystem services. Trends in Ecology \& Evolution 30:190-198. DOI: 10.1016/j.tree.2015.01.011

Oksanen J, Blanchet FG, Friendly M, Kindt R, Legendre P, McGlinn D, Minchin PR, O'Hara RB, Simpson GL, Solymos P, Stevens MHH, Szoecs E, and Wagner H. 2007. The vegan 
806

807

808

809

810

811

812

813

814

815

816

817

818

819

820

821

822

823

824

825

826

827

828

829

830

831

832

833

834

835

836

837

838

839

840

841

842

843

844

845

846

847

848

849

package. Community ecology package. Available at https://cran.rproject.org/web/packages/vegan/index.html (accessed 12 september 2018)

Olea PP, and Mateo Tomás P. 2009. The role of traditional farming practices in ecosystem conservation: the case of transhumance and vultures. Biological Conservation 142: 18441853. DOI: $10.1016 / \mathrm{j}$. biocon.2009.03.024

Olff H, and Ritchie ME. 1998. Effects of herbivores on grassland plant diversity. Trends in Ecology \& Evolution 13:261-265. DOI: 10.1016/S0169-5347(98)01364-0

Osem Y, Perevolotsky A, and Kigel J. 2002. Grazing effect on diversity of annual plant communities in a semi-arid rangeland: interactions with small-scale spatial and temporal variation in primary productivity. Journal of Ecology 90:936-946. DOI: 10.1046/j.13652745.2002.00730.x

Oteros-Rozas E, González JA, Martín-López B, López CA, Zorrilla-Miras P, and Montes C. 2012. Evaluating ecosystem services in transhumance cultural landscapesan interdisciplinary and participatory framework. Gaia-Ecological Perspectives for Science and Society 21:185-193.

Ouborg N, Vergeer P, and Mix C. 2006. The rough edges of the conservation genetics paradigm for plants. Journal of Ecology 94:1233-1248. DOI: 10.1111/j.1365-2745.2006.01167.x

Peakall R, and Smouse PE. 2012. GenAlEx 6.5: genetic analysis in Excel. Population genetic software for teaching and research—an update. Bioinformatics 28:2537-2539. DOI: 10.1093/bioinformatics/bts460

Peco B, Traba J, Levassor C, Sánchez AM, and Azcárate FM. 2003. Seed size, shape and persistence in dry Mediterranean grass and scrublands. Seed Science Research 13:87-95. DOI: $10.1079 /$ SSR2002127

Peco B, de Pablos I, Traba J, and Levassor C. 2005. The effect of grazing abandonment on species composition and functional traits: the case of dehesa grasslands. Basic and Applied Ecology 6:175-183. DOI: 10.1016/j.baae.2005.01.002

Peco B, Lopez-Merino L, and Alvir M. 2006. Survival and germination of Mediterranean grassland species after simulated sheep ingestion: ecological correlates with seed traits. Acta Oecologica 30:269-275. DOI: 10.1016/j.actao.2006.05.004

Pires MM, Galetti M, Donatti CI, Pizo MA, Dirzo R, and Guimarães PR. 2014. Reconstructing past ecological networks: the reconfiguration of seed-dispersal interactions after megafaunal extinction. Oecologia 175:1247-1256. DOI: 10.1007/s00442-014-2971-1

Piry S, Luikart G, and Cornuet J-M. 1999. Computer note. BOTTLENECK: a computer program for detecting recent reductions in the effective size using allele frequency data. Journal of Heredity 90:502-503. DOI: 10.1093/jhered/90.4.502

Plue J, Vandepitte K, Honnay O, Cousins SAO. 2017. Does the seed bank contribute to the build-up of a genetic extinction debt in the grassland perennial Campanula rotundifolia? Annals of Botany 120: 373-385. DOI: 10.1093/aob/mcx057

Plue J, Aavik T, and Cousins SAO. 2019. Grazing networks promote plant functional connectivity among isolated grassland communities. Diversity and Distributions, 25: 102-115. DOI: $10.1111 /$ ddi. 12842

Poschlod P, Kiefer S, Tränkle U, Fischer S, and Bonn S. 1998. Plant species richness in calcareous grasslands as affected by dispersability in space and time. Applied Vegetation Science 1: 75-91. DOI: 10.2307/1479087 
850 Pretelli MG, Isacch JP, Cardoni DA. 2018. Species-Area Relationships of Specialist Versus 851 Opportunistic Pampas Grassland Birds Depend on the Surrounding Landscape Matrix.

852

853

854

855

856

857

858

859

860

861

862

863

864

865

866

867

868

869

870

871

872

873

874

875

876

877

878

879

880

881

882

883

884

885

886

887

888

889

890

891

892

893

Ardeola, 65: 3-23. DOI: 10.13157/arla.65.1.2018.ra1

Puechmaille SJ. 2016. The program structure does not reliably recover the correct population structure when sampling is uneven: subsampling and new estimators alleviate the problem. Molecular Ecology Resources, 16: 608-627. DOI: 10.1111/1755-0998.12512

Rico Y, Boehmer H.J, and Wagner HH. 2014a. Effect of rotational shepherding on demographic and genetic connectivity of calcareous grassland plants. Conservation biology, 28: 467477. DOI: $10.1111 /$ cobi.12186

Rico Y, Holderegger R, Boehmer HJ, and Wagner HH. 2014b. Directed dispersal by rotational shepherding supports landscape genetic connectivity in a calcareous grassland plant. Molecular ecology, 23: 832-842. DOI: 10.1111/mec.12639.

Rico Y, and Wagner H. 2016. Reduced fine-scale spatial genetic structure in grazed populations of Dianthus carthusianorum. Heredity 117:367. DOI: 10.1038/hdy.2016.45

Ripple WJ, Estes JA, Beschta RL, Wilmers CC, Ritchie EG, Hebblewhite M, Berger J, Elmhagen B, Letnic M, Nelson MP, Schmitz OJ, Smith DW, Wallach AD, and Wirsing AJ. 2014. Status and ecological effects of the world's largest carnivores. Science 343:1241484. DOI: $10.1126 /$ science. 1241484

Rosenberg NA. 2004. DISTRUCT: a program for the graphical display of population structure. Molecular Ecology Resources 4:137-138. DOI: 10.1046/j.1471-8286.2003.00566.x

Said MY, Ogutu JO, Kifugo SC, Makui O, Reid RS, and de Leeuw J. 2016. Effects of extreme land fragmentation on wildlife and livestock population abundance and distribution. Journal for Nature Conservation 34:151-164. DOI: 10.1016/j.jnc.2016.10.005

Sharma N, Koul P, and Koul AK. 1993. Pollination biology of some species of genus Plantago L. Botanical Journal of the Linnean Society 111:129-138. DOI: 10.1006/boj1.1993.1011

Smith RM, and Botha-Brink J. 2014. Anatomy of a mass extinction: sedimentological and taphonomic evidence for drought-induced die-offs at the Permo-Triassic boundary in the main Karoo Basin, South Africa. Palaeogeography, Palaeoclimatology, Palaeoecology 396:99-118. DOI: 10.1016/j.palaeo.2014.01.002

Smith SE, Arredondo T, Aguiar M, Huber-Sannwald E, Alpuche A, Aguado A, Grageda OA, Halbrook K, and Bottini C. 2009. Fine-scale spatial genetic structure in perennial grasses in three environments. Rangeland Ecology \& Management 62:356-363. DOI: 10.2111/08-159.1

Starrs P. 2018. Transhumance as Antidote for Modern Sedentary Stock Raising. Rangeland Ecology \& Management 71:592-602. DOI: 10.1016/j.rama.2018.04.011

Suárez-Esteban A, Delibes M, and Fedriani JM. 2013. Barriers or corridors? The overlooked role of unpaved roads in endozoochorous seed dispersal. Journal of Applied Ecology 50:767774. DOI: $10.1111 / 1365-2664.12080$

Thackeray SJ, Henrys PA, Hemming D, Bell JR, Botham MS, Burthe S, Helaouet P, Johns DG, Jones ID, Leech DI, Mackay EB, Massimino D, Atkinson S, Bacon PJ, Brereton TM, Carvalho L, Clutton-Brock TH, Duck C, Edwards M, Elliott JM, Hall SJG, Harrington R, Pearce-Higgins JW, Høye TT, Kruuk LEB, Pemberton JM, Sparks TH, Thompson PM, White I, Winfield IJ, and Wanless S. 2016. Phenological sensitivity to climate across taxa and trophic levels. Nature 535:241-245. DOI: 10.1038/nature18608

Peer) reviewing PDF | (2018:09:31235:2:0:NEW 6 Jun 2019) 
894 Turner ME, Stephens JC, Anderson WW. 1982. Homozygosity and patch structure in plant 895 populations as a result of nearest-neighbor pollination. Proceedings of the National Academy of Sciences of the USA 79: 203-207

Untergasser A, Cutcutache I, Koressaar T, Ye J, Faircloth BC, Remm M, and Rozen SG. 2012. Primer3 - new capabilities and interfaces. Nucleic Acids Research 40:e115-e115. DOI: 10.1093/nar/gks596

Van Etten ML, Tate JA, Anderson SH, Kelly D, Ladley JJ, Merrett MF, Peterson PG, and Robertson AW. 2015. The compounding effects of high pollen limitation, selfing rates and inbreeding depression leave a New Zealand tree with few viable offspring. Annals of Botany 116:833-843. DOI: 10.1093/aob/mcv118

van Oosterhout C, Hutchinson WF, Wills DP, and Shipley P. 2004. MICRO-CHECKER: software for identifying and correcting genotyping errors in microsatellite data. Molecular Ecology Resources 4: 535-538. DOI: 10.1111/j.1471-8286.2004.00684.x

Wang BC, and Smith TB. 2002. Closing the seed dispersal loop. Trends in Ecology \& Evolution 17:379-386. DOI: 10.1016/S0169-5347(02)02541-7

Wichmann MC, Alexander MJ, Soons MB, Galsworthy S, Dunne L, Gould R, Fairfax C, Niggemann M, Hails RS, and Bullock JM. 2009. Human-mediated dispersal of seeds over long distances. Proceedings of the Royal Society of London B: Biological Sciences 276:523-532. DOI: 10.1098/rspb.2008.1131

Wilson GA, and Rannala B. 2003. Bayesian inference of recent migration rates using multilocus genotypes. Genetics 163:1177-1191. DOI:

Wilson JR, Dormontt EE, Prentis PJ, Lowe AJ, and Richardson DM. 2009. Something in the way you move: dispersal pathways affect invasion success. Trends in Ecology \& Evolution 24:136-144. DOI: 10.1016/j.tree.2008.10.007

Willerding C, and Poschlod P. 2002. Does seed dispersal by sheep affect the population genetic structure of the calcareous grassland species Bromus erectus? Biological Conservation 104:329-337. DOI: 10.1016/S0006-3207(01)00198-7 


\section{Table $\mathbf{1}$ (on next page)}

Location and genetic descriptors for studied populations.

$\mathrm{N}$ stands for number of individuals analyzed. Genetic diversity descriptors (I, Shannon information index; $A_{P}$, total number of private alleles, $H_{O}$ observed heterocigosity, $H_{E}$ expected heterozygosity), $F_{I S}$, inbreeding coefficient and number of alleles deviated from Hardy-Weinberg equilibrium are provided. RiqRare stands for rarefacted allelic richness, and PrivRare for average rarefacted number of private alleles. Average for drove road (LCR) and matrix (LMA) populations are also given. 


\begin{tabular}{|c|c|c|c|c|c|c|c|c|c|}
\hline Population & Coordinates & $\mathbf{N}$ & $I$ & $A_{P}$ & $H_{O}$ & $H_{E}$ & $F_{I S}-\mathrm{HW}$ & RiqRare & PrivRare \\
\hline LCR01 & $39.43 \mathrm{~N}, 2.62 \mathrm{~W}$ & 30 & 2.46 & 6 & 0.37 & 0.93 & $0.17-4$ & 9.4 & 0.5 \\
\hline LCR02 & $39.39 \mathrm{~N}, 2.67 \mathrm{~W}$ & 10 & 2.03 & 1 & 0.82 & 0.88 & $0.10-1$ & 8.8 & 0.2 \\
\hline LCR04 & $39.34 \mathrm{~N}, 2.77 \mathrm{~W}$ & 10 & 2.29 & 4 & 0.89 & 0.88 & $0.01-1$ & 10.2 & 0.7 \\
\hline LCR06 & $39.26 \mathrm{~N}, 2.81 \mathrm{~W}$ & 13 & 2.21 & 2 & 0.84 & 0.88 & $0.09-3$ & 9.3 & 0.6 \\
\hline LCR09 & $39.13 \mathrm{~N}, 2.84 \mathrm{~W}$ & 14 & 2.11 & 2 & 0.89 & 0.87 & $0.02-4$ & 8.6 & 0.8 \\
\hline LCR10 & $39.08 \mathrm{~N}, 2.84 \mathrm{~W}$ & 8 & 1.88 & 1 & 0.79 & 0.86 & $0.11-1$ & 8.3 & 0.6 \\
\hline $\begin{array}{l}\text { LCR average } \\
\text { (CV) }\end{array}$ & & & $\begin{array}{r}2.16 \\
(0.09)\end{array}$ & 2.7 & $\begin{array}{c}0.76 \\
(0.24)\end{array}$ & $\begin{array}{c}0.88 \\
(0.02)\end{array}$ & $\begin{array}{c}0.08 \\
(0.73)\end{array}$ & $\begin{array}{c}9.1 \\
(0.07)\end{array}$ & 0.6 \\
\hline LMA05 & $39.27 \mathrm{~N}, 2.61 \mathrm{~W}$ & 10 & 2.21 & 3 & 0.85 & 0.89 & $0.06-2$ & 9.8 & 0.5 \\
\hline LMA08 & $39.16 \mathrm{~N}, 2.99 \mathrm{~W}$ & 30 & 2.49 & 12 & 0.78 & 0.84 & $0.14-4$ & 9.6 & 0.8 \\
\hline LMA11 & $39.41 \mathrm{~N}, 2.93 \mathrm{~W}$ & 14 & 2.29 & 1 & 0.86 & 0.89 & $0.11-2$ & 9.4 & 0.3 \\
\hline LMA12 & $39.49 \mathrm{~N}, 2.81 \mathrm{~W}$ & 10 & 2.04 & 5 & 0.89 & 0.89 & $0.1-3$ & 8.8 & 0.8 \\
\hline LMA13 & $39.26 \mathrm{~N}, 2.76 \mathrm{~W}$ & 13 & 2.47 & 1 & 0.88 & 0.92 & $0.09-3$ & 10.7 & 0.6 \\
\hline LMA14 & $39.11 \mathrm{~N}, 2.61 \mathrm{~W}$ & 10 & 1.42 & 1 & 0.75 & 0.86 & $0.17-2$ & 5.1 & 0.4 \\
\hline LMA16 & $39.06 \mathrm{~N}, 2.66 \mathrm{~W}$ & 14 & 1.99 & 3 & 0.84 & 0.91 & $0.11-2$ & 7.9 & 0.4 \\
\hline $\begin{array}{l}\text { LMA average } \\
(\mathrm{CV})\end{array}$ & & & $\begin{array}{r}2.13 \\
(0.17) \\
\end{array}$ & 4.5 & $\begin{array}{c}0.83 \\
(0.06) \\
\end{array}$ & $\begin{array}{c}0.89 \\
(0.03) \\
\end{array}$ & $\begin{array}{c}0.11 \\
(0.35) \\
\end{array}$ & $\begin{array}{c}8.7 \\
(0.21) \\
\end{array}$ & 0.5 \\
\hline
\end{tabular}

1 


\section{Table 2 (on next page)}

Bottleneck output for heterozygosity excess (population bottlenecks) in 13 studied populations of Plantago lagopus.

The output is provided under three evolutive models: Infinite Allele model (IAM), Two-phase Model (TPM) and Stepwise Mutation Model (SMM). Significant values after Wilcoxon sign-rank test with Bonferroni correction are highlighted in bold. Population code are belong into Drove Road (LCR code) or Matrix (LMA code) populations. 
1

\begin{tabular}{|l|c|c|c|}
\hline & IAM & TPM & SMM \\
\hline LCR01 & 0.43 & 0.84 & 0.11 \\
\hline LCR02 & 0.57 & 0.57 & 0.84 \\
\hline LCR04 & 0.15 & 0.43 & 1 \\
\hline LCR06 & 1 & 0.43 & 0.15 \\
\hline LCR09 & 0.15 & 0.15 & $\mathbf{0 . 0 1}$ \\
\hline LCR10 & 1 & 0.84 & 0.84 \\
\hline LMA05 & 0.68 & 1 & 0.11 \\
\hline LMA08 & 0.56 & 0.56 & $\mathbf{0 . 0 3}$ \\
\hline LMA11 & 0.43 & 0.56 & $\mathbf{0 . 0 3}$ \\
\hline LMA12 & 0.43 & 0.43 & 1 \\
\hline LMA13 & 0.56 & 1 & 0.84 \\
\hline LMA14 & $\mathbf{0 . 0 1}$ & 0.11 & 0.56 \\
\hline LMA16 & 0.68 & 0.84 & 0.15 \\
\hline
\end{tabular}

2 


\section{Table 3 (on next page)}

Summary of the average rate ( \pm standard deviation) of gene flow received from each population.

The gene flow is estimated with BayesAss $(\mathrm{m})$ and Migrate $\left(N_{e} \mathrm{~m}\right)$ software. Average \pm SD for location (drove road and matrix) have been also calculated. 


\begin{tabular}{|l|c|c|}
\hline Population & BayesAss & Migrate \\
\hline LCR01 & $0.021 \pm 0.016$ & $16.77 \pm 5.69$ \\
\hline LCR02 & $0.012 \pm 0.003$ & $20.23 \pm 6.29$ \\
\hline LCR04 & $0.012 \pm 0.003$ & $16.96 \pm 8.77$ \\
\hline LCR06 & $0.013 \pm 0.003$ & $16.58 \pm 8.13$ \\
\hline LCR09 & $0.013 \pm 0.003$ & $12.58 \pm 4.99$ \\
\hline LCR10 & $0.013 \pm 0.002$ & $6.95 \pm 4.13$ \\
\hline LCR average & $0.014 \pm 0.003$ & $15.01 \pm 4.63$ \\
\hline LMA05 & $0.013 \pm 0.002$ & $10.64 \pm 5.47$ \\
\hline LMA08 & $0.11 \pm 0.067$ & $20.03 \pm 9.18$ \\
\hline LMA11 & $0.013 \pm 0.003$ & $17.04 \pm 6.76$ \\
\hline LMA12 & $0.013 \pm 0.003$ & $15.58 \pm 7.07$ \\
\hline LMA13 & $0.013 \pm 0.003$ & $13.08 \pm 6.16$ \\
\hline LMA14 & $0.013 \pm 0.003$ & $14.91 \pm 7.36$ \\
\hline LMA16 & $0.04 \pm 0.03$ & $17.36 \pm 9.88$ \\
\hline LMA average & $0.031 \pm 0.036$ & $15.52 \pm 3.06$ \\
\hline
\end{tabular}




\section{Table 4 (on next page)}

Results of linear modeling of the inbreeding depression $\left(F_{I S}\right)$, rarefacted allelic richness $\left(A_{r}\right)$ and nestedness on landscape factors.

The linear predictor is built with the population position (drove road / agricultural matrix), the distance to the nearest settlement, the availability of neighboring grasslands (only for $\mathrm{F}_{\mathrm{Is}} ; \log$ transformed) and the interaction between position and distance. Landscape descriptors were standardized and centered. Models were fitted using generalized least squares (GLS) with three alternative spatial correlation structures (Gaussian, exponential, spherical) for the residuals, to account for potential spatial autocorrelation. We show here the best models according to AICc. The log-likelihood ratio test $\left(\chi^{2}\right)$ is given after comparison with a null model with the same spatial structure and corresponding $p$-value, as well as an approximation to $\mathrm{R}^{2}$ as the squared Pearson correlation between predicted and observed values, and coefficient estimates (with standard errors) and p-values from a type-II sum of squares for the explanatory variables (note that coefficient for 'Position' factor refers to 'drove road' level, while the accompanying $p$-value is for the factor as a whole). Significant $p$-values $(p<0.05)$ are highlighted in bold. 


\begin{tabular}{|c|c|c|c|}
\hline Genetic descriptors & & Coefficient estimate & $p$ \\
\hline \multirow[t]{6}{*}{$\mathrm{F}_{\mathrm{IS}}$} & $\begin{array}{l}\chi^{2}{ }_{5}=20.82, R^{2}=26 \% \text {, Gaussian spatial } \\
\text { covariance structure. }\end{array}$ & & 0.001 \\
\hline & Intercept & $0.139(0.028)$ & \\
\hline & Distance to settlement & $0.015(0.032)$ & $<0.0001$ \\
\hline & Position (drove road) & $-0.015(0.025)$ & 0.280 \\
\hline & Grassland cover & $0.037(0.009)$ & $<0.0001$ \\
\hline & Distance $\mathrm{x}$ Position & $-0.106(0.037)$ & 0.005 \\
\hline \multirow[t]{5}{*}{$A_{r}$} & $\begin{array}{l}\chi_{4}^{2}=10.51, R^{2}=72 \%, \text { Gaussian spatial } \\
\text { covariance structure. }\end{array}$ & & 0.033 \\
\hline & Intercept & $8.056(0.459)$ & \\
\hline & Distance to settlement & $-1.724(0.548)$ & 0.006 \\
\hline & Position (drove road) & $1.254(0.666)$ & 0.076 \\
\hline & Distance $\mathrm{x}$ Position & $1.282(0.705)$ & 0.070 \\
\hline \multirow[t]{5}{*}{ Nestedness } & $\chi^{2}{ }_{4}=11.68, \mathrm{R}^{2}=29 \%$ & & 0.019 \\
\hline & Intercept & $5.620(1.354)$ & \\
\hline & Distance to settlement & $-3.711(1.558)$ & 0.416 \\
\hline & Position & $2.470(1.894)$ & 0.404 \\
\hline & Distance $\mathrm{x}$ Position & $1.094(2.420)$ & 0.160 \\
\hline
\end{tabular}




\section{Figure 1}

\section{Study area.}

Left panel: localization map of the sampled points within the Iberian Peninsula. Base map by maps-forfree.com

Right panel: inset with location of sampling points on a simplified landcover map of the study area (elaborated with data compiled between 2009-2011 and provided by the National Geographic Institute at http://www.siose.es ). Points were sampled in the drove road (circles, labelled 'CR') and in the agricultural matrix (stars, labelled 'MA'). The drove road ('Cañada Real Conquense'), depicted with broad green line, crosses a landscape formed predominantly by crops (pale yellow) and patches of woodlands (pale green), shrublands (brown) and grasslands (yellow). Urban and non-vegetated areas are shown in red.

Lower panel: Picture of the Conquense Drove Road between La Almarcha and Villar de la Encina in late spring, with transiting transhumant livestock herd. Note the longitudinal pasture with ripe grass, surrounded by agricultural fields. Image courtesy of José Antonio González. 


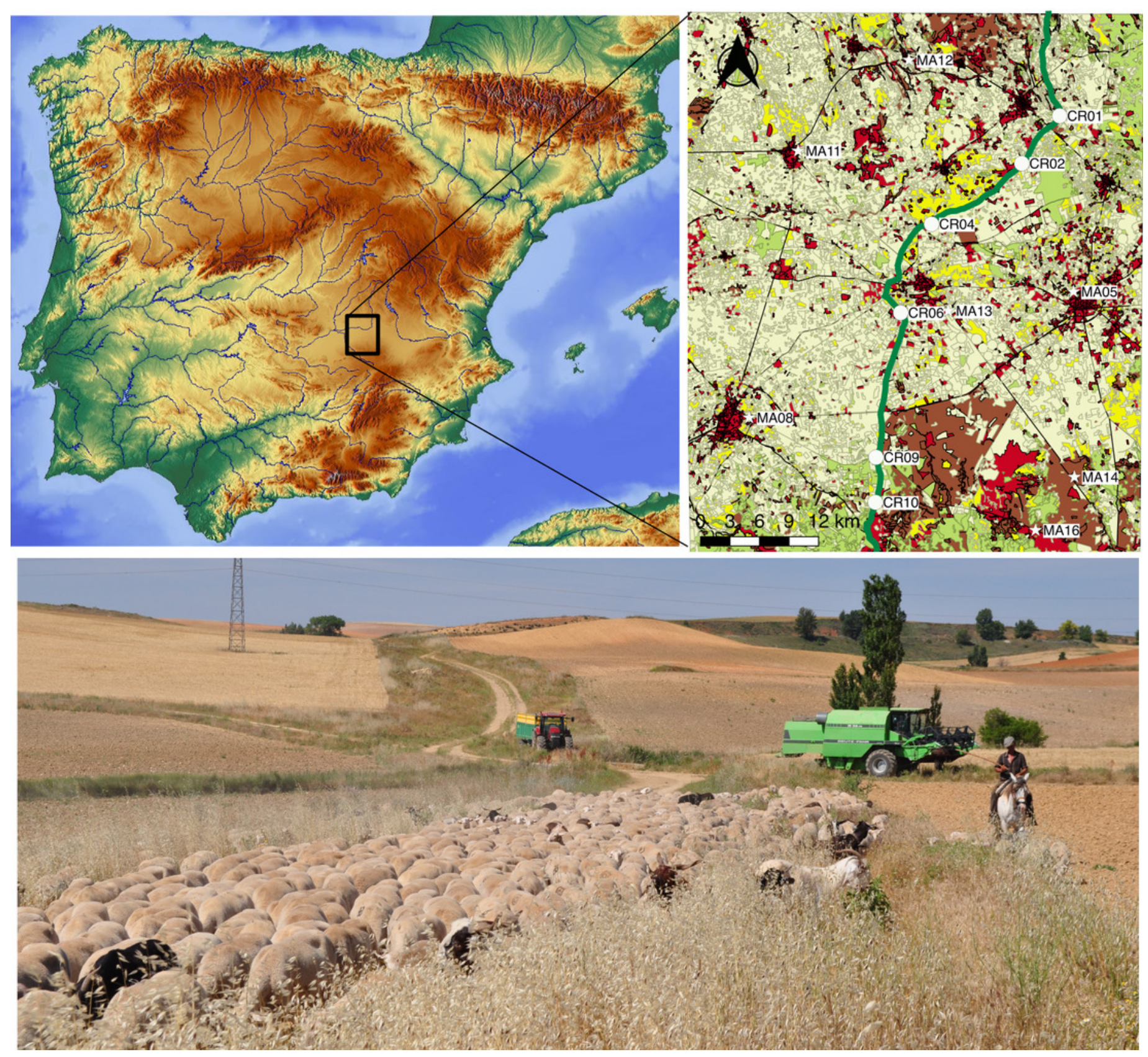




\section{Figure 2}

Bayesian genetic structure results obtained with STRUCTURE.

Number of clusters proposed by Evanno method (A). Number of clusters proposed MedMedK

(B), MedMeanK (C), MaxMedK (D) and MaxMeanK (E). Genetic structure proposed for $K=4$

(F). Genetic structure proposed for $K=12(\mathrm{G})$.
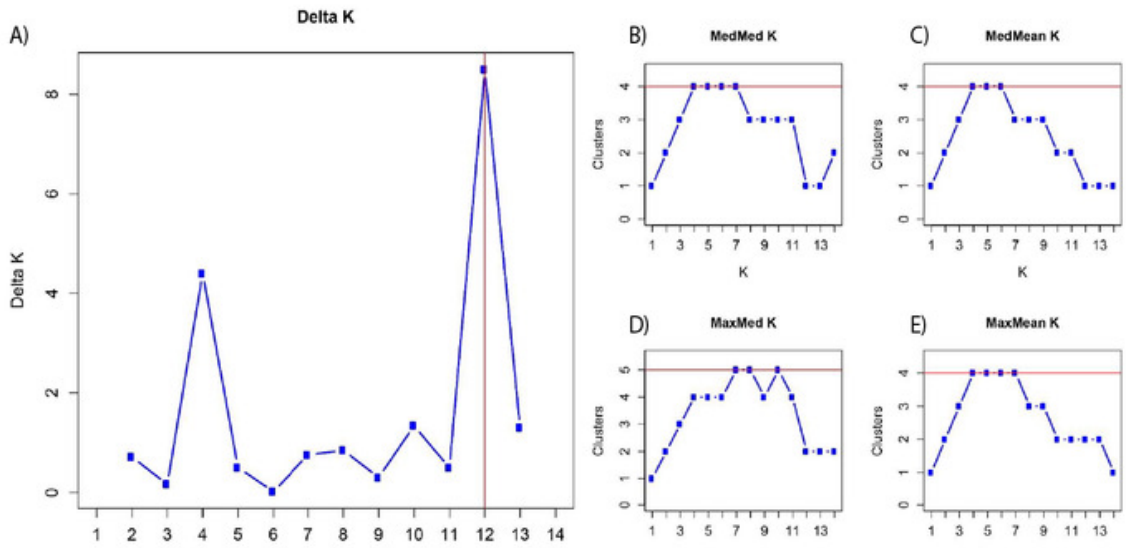

F)
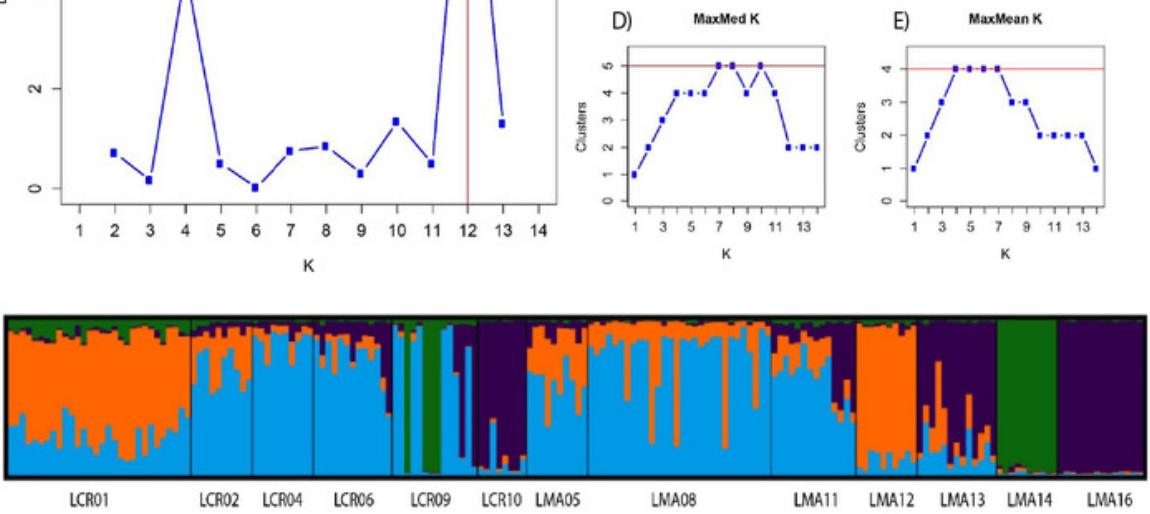

G)

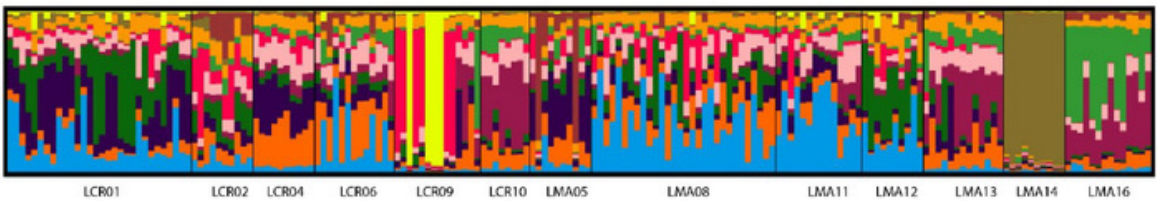


Figure 3

Contemporary (BayesAss) and historical (Migrate) rates of gene flow among the Plantago lagopus populations.

Matrix (LMA) populations are represented with red circles, while Cañada (LCR) populations are surrounded by green circles. The width of the edges is proportional to $m$ and $N_{e} m$ values respectively.
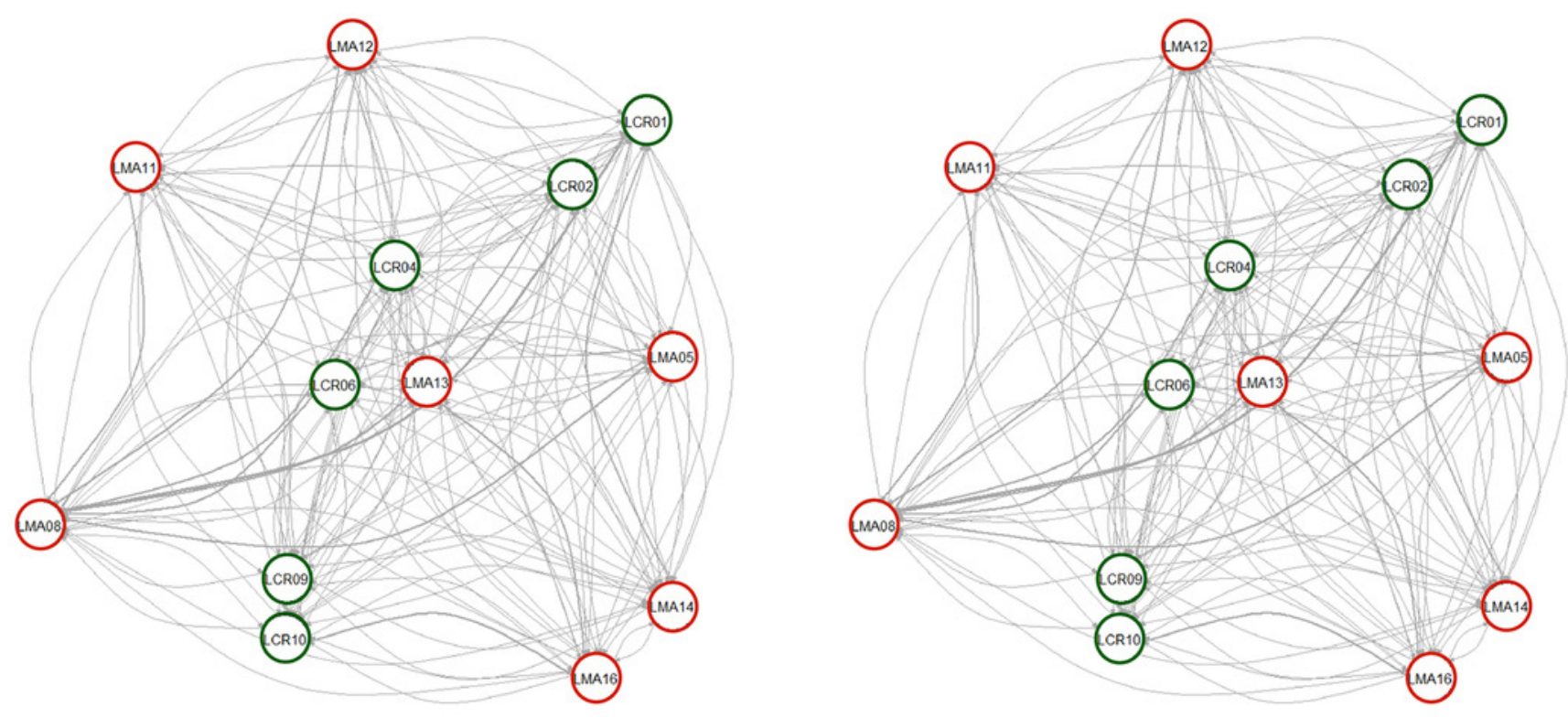
Figure 4

Relationship between genetic and geographic parameters.

Linear regressions are shown between distance to closest settlement for populations in the agricultural matrix (solid circles and solid line) and those in the drove road (open triangles and dashed line), and genetic descriptors: (A) $F_{15}$ for inbreeding, and (B) $A_{r}$ (rarefacted allelic richness) for diversity.
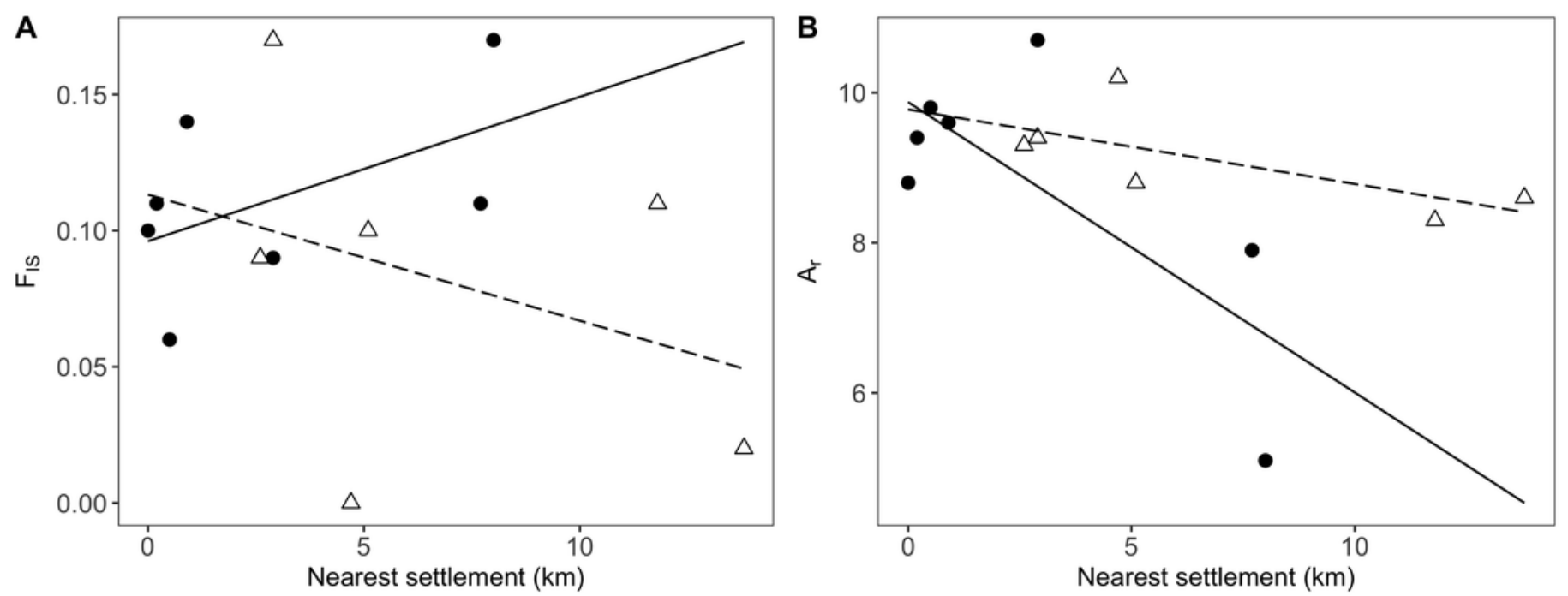